\title{
Heat Tolerant Traits among Local and Exotic Chickens in Southern Nigerian
}

\author{
Isidahomen, C. E. ${ }^{1}$ Njidda, A. A. ${ }^{2}$, Olatunji, E. A ${ }^{3}$ \\ ${ }^{I}$ Department of Animal Science, Ambrose Alli University, P.M.B. 14, Ekpoma, Edo State, Nigeria \\ ${ }^{2,3}$ Department of Animal Science, Bayero University, Kano P.M.B. 3011, Kano State, Nigeria
}

\begin{abstract}
The research was carried out to study the physiological traits among local chickens by determining the effect of genotype on the rectal temperature, pulse rate and respiratory rate. A total of two hundred and fifty (250) chickens were used for this study. These consisted of 50 birds each of normal feather, naked neck and frizzled matured chicken's genotypes. Under natural heat stress environment genotype were significantly $(P<0.05)$ affected by rectal temperature, pulse rate and respiratory rate. The naked neck had the highest value of rectal temperature, while normal feather recorded the lowest values of $40.09 \pm 0.21^{\circ} \mathrm{C}$ to $41.05 \pm 0.08^{\circ} \mathrm{C}$ beat/min. The highest value for respiratory rate was observed in naked neck strain, while normal feather strain had the least value of $(64.80 \pm 2.60$ to $22.00 \pm 149 \mathrm{breath} / \mathrm{min})$. On pulse rate, naked neck feather strain had the

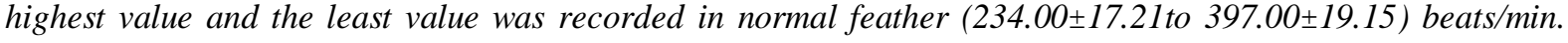
Haematological and serum biochemical parameters of chickens were also evaluated. There were significant $(P<0.05)$ differences between the genotypes in the mean values of packed cell volume $(P C V)$ red blood cell $(R B C)$ count, white blood cell (WBC) count, haemoglobin concentration (Hb), mean corpuscular volume $(\mathrm{MCV})$, mean corpuscular haemoglobin $(\mathrm{MCH})$ and mean corpuscular haemoglobin concentration $(\mathrm{MCHC})$. However the frizzle was significantly superior in all the parameters examined. Also RBC was significantly $(P<0.05)$ higher in the frizzle $(3.18 \pm 0.09,3.32 \pm 0.01$ and2.85 \pm 0.15$)$. There were significant $(P<0.05)$ differences between the genotypes in the total protein, albumin, cholesterol, urea, creatinine, full blood count, calcium and phosphorus of the genetic groups. The normal matured chicken genotype however, had the highest significant albumin $(1.61 \pm 0.031 .74 \pm 0.05$, and $1.90 \pm 0.07 \mathrm{ml})$ and a lower creatinine value $(0.45 \pm 0.11,0.86 \pm 0.08$, and $0.44 \pm 0.04 \mathrm{ml}$ ) compared to the other chicken genotypes. It can therefore be concluded that variations in the genetic make-up of the chickens accounted for the observed differences in heat tolerance traits, haematology and serum biochemical. It can therefore be concluded that variations in the genetic make-up of the chickens accounted for the observed differences in physiological traits. The present result showed that genotype can significantly affect the physiological of chickens with respect to blood, rectal temperature pulse rate, and respiratory rate can be used for selection in order to select the best performing genotype for the environment.
\end{abstract}

Keywords: Haematological, Genotype, Naked neck. Frizzle. Normal feather, chickens.

\section{Introduction}

The ability of an animal to maintain homeostasis under heat stress is a valuable trait in the sub tropical and tropical region. The main indicator of heat stress is prolonged panting [1]. Heat is produced by metabolism within the body, which includes maintainers, growth and egg production. Heat production is affected by body weight, species and breed, level of production, level of feed intake and to a lesser extent, by the amount of activity and exercise, and these conditions reduces growth rate and production [2].

The internal body temperature of domestic poultry is normally $41.2-42.2^{\circ} \mathrm{C}$ considerably higher than that of mammals $\left(36-39^{\circ} \mathrm{C}\right)$. The fundamental problem facing domestic poultry exposed to extremes of temperature is to maintain their body in a condition, which permits the normal functioning of the chemical process.. Below the zone of the thermal neutrality, food is used wastefully and above this zone the bird suffers heat stress [3]. There is a need therefore to continually review and re-evaluate the management of poultry and equipment used in hot weather, so that heat stress and the associated welfare problems are minimized.

\section{Materials And Methods}

\subsection{Description of Study area:}

The research was carried out at the Poultry Unit of the Livestock Teaching and Research Farm of Ambrose Alli University, Ekpoma, Edo State. The farm lies between Lat $6.44^{\circ} \mathrm{N}$ and Log $6.8^{\circ} \mathrm{E}$ in Esan West Local Government Area of Edo State, Nigeria. Ekpoma is within the South-South geo-political zone of Nigeria and has a prevailing tropical climate with a mean annual rainfall of about $1556 \mathrm{~mm}$. The mean ambient temperature ranges from $26^{\circ} \mathrm{C}$ in December to $34^{\circ} \mathrm{C}$ in February, relative humidity ranges from $61 \%$ in January 
to $92 \%$ in August with yearly average of about $82 \%$. The vegetation represents an interface between the tropical rainforest and the derived savanna.

\subsection{Management of the birds:}

A total of 250 chickens were used for this study. These consisted of 50 birds each of naked neck, frizzled and normal feather chickens genotypes. The genetic group contributed varied number of chicks and chicks generated were reared for 25 weeks. All chicks were wing tagged for proper identification and subjected to the same management practice throughout the experimental period. The chicks were brooded for four 4 weeks with a brooding temperature of $34^{\circ} \mathrm{C}$. Medication and vaccinations were carried out accordingly against stress and disease.

\subsection{Feeds and Feeding:}

The birds were fed adlibitum with starter marsh containing $20 \%$ crude protein, 2996Kcal $/ \mathrm{kg}$ Metabolizable Energy from Dayold-4weeks of age, Growers marsh containing $15.86 \%$ crude protein, $2716 \mathrm{Kcal} / \mathrm{kg}$ Metabolizable Energy from 4-15weeks of age. Breeder's marsh containing $16.80 \%$ crude protein, $2823 \mathrm{Kcal} / \mathrm{kg}$ Metabolizable Energy from 15-24weeks of age. Clean water was supplied continuously ad libitum throughout the experimental period.

Table 1. Composition of the experimental diets.

\begin{tabular}{llll}
\hline Ingredient & Starter diet & Growers diet & Breeders diet \\
\hline Maize & 45.95 & 55.45 & 56.95 \\
Groundnut cake & 25.00 & 15.00 & 20.00 \\
Wheat offal & 18.00 & 20.00 & 15.00 \\
Fish Meal & 3.00 & 1.50 & 2.00 \\
Bone Meal & 2.00 & 2.00 & 2.00 \\
Limestone & 5,00 & 5.00 & 5.00 \\
*Premix & 0.25 & 0.25 & 0.25 \\
Salt & 0.30 & 0.30 & 0.30 \\
Lysine & 0.25 & 0.25 & 0.25 \\
Methionine & 0.25 & 0.25 & 0.25 \\
\hline Total & 100.00 & 100.00 & 100.00 \\
\hline Calculated CP $(\%)$ & 20.17 & 15.86 & 16.80 \\
ME ( kcal/kg) & 2996.40 & 2716.00 & 2823.14 \\
\hline
\end{tabular}

*Premixcontained:VitaminA1500i.u;VitD 3 ,3000iu;VitE12,iu;VitaminK2.4mg;thiamine3.0mg;Riboflav in,6.0mg;pyriooxine $4.8 \mathrm{mg} ; 1000 \mathrm{mg}$;nicotinic acid $43 \mathrm{mg}$;calcium panthotenic acid $12 \mathrm{mg} ; 0.6 \mathrm{mg}$;Vitamin B12 $0.024 \mathrm{mg}$; vitamin B2 $5 \mathrm{mg}$; folic acid 12mg; chlorine chloride,350mg manganese, $56 \mathrm{mg}$, Iodin $1 \mathrm{mg}$; Zinc 50mg, copper, $400 \mathrm{mg}$; Iodine, $20 \mathrm{mg}$; cobalt, $1.25 \mathrm{mg}$, selenium ,4.8mg

\subsection{Heat tolerance Trait}

Data Analysis: Data was collected on a weekly basis for 24weeks.Parameters measured are:

\section{Rectal temperature:}

This was measured using a clinical thermometer inserted it into the vent for 1 minute after which the readings were taken

\section{Respiration rate: $\mathrm{T}$}

his was determined for each bird by counting the number of movements of abdominal region or vent using stopwatch.

Pulse rate:

This was determined by placing the finger tips under the wing vein and counting the number of beats per minutes using a stop watch.

\section{Heat stress index:}

The heat stress index was derived from the relationship between pulse rate and respiratory rate together with their normal average values. The formula was as follows

$\mathrm{H}=(\mathrm{AR} / \mathrm{AP}) \times(\mathrm{NP} / \mathrm{NR})$

$\mathrm{H}=$ Heat stress index

$\mathrm{AR}=$ average respiratory rate value

$\mathrm{AP}=$ Average pulse value

$\mathrm{NP}=$ Normal pulse rate value

$\mathrm{NR}=$ Normal respiratory rate [4] 


\subsection{Blood sample collection}

Blood sample was collected before and after the end of the experiment. Fasting was done over night and blood was collected from the Jugular veins. Specimen for haematological studies were collected separately in a bottle containing dipotassium salts of ethylene diamine tetra-acetic acid (EDTA) as anticoagulant while, anticoagulant free tubes were used for biochemical analyses. The blood samples were analysed using routinely available clinical methods. These include packed cell volume (PCV) or haematocrit, red blood cell (RBC) count and white blood cell (WBC) count and haemoglobin concentration ( $\mathrm{Hb})$, using Witrob's micro-haematocrit, improved Neubaur haemocytometer and cyanomethaemoglobin methods respectively. The erythrocyte indices, mean corpuscular volume (MCV), mean corpuscular haemoglobin (MCHC) were computed according to Jain [5]. Serum protein, albumen, globulin and urea were analysed using sigma assay kits, while glucose and creatinine were determined according to Slot [6], uric acid [7] and cholesterol [8]. Blood sample were collected from the jugular veins using sterile disposable needles (21-guage) and syringes. Before the blood collection, the birds were fasted over night for 12 hours and bled the next morning to avoid excessive bleeding. Samples for biochemical indices analysis were collected into anti-coagulant free tubes and allowed to clot. Serum was obtained after the blood samples had been allowed to stand for two hours at room temperature and centrifuged for ten minutes at $2000 \mathrm{rpm}$ to separate the cell from the serum.

\subsection{Experimental design and statistical analyses}

Data obtained for heat tolerance traits were analyzed using the General Linear Model [9]. Significant differences were computed using New Duncan's Multiple Range Test was used to separate the means that are significantly difference [10].

. The model was as specified below:

$\mathrm{Y}_{\mathrm{ijk}}=\mu+\mathrm{G}_{\mathrm{i}}+\sum_{\mathrm{ij}}$

where

$\mathrm{Y}_{\mathrm{ijk}}=$ Dependent Variable

$\mu \quad=$ overall mean for the parameter of interest

$\mathrm{G}_{\mathrm{i}}=$ Effect of the $\mathrm{i}^{\text {th }}$ genotype on physiological traits

$\sum_{\mathrm{ijk}}=\quad$ Random Residual error

\section{Results}

\subsection{Effect of Genotype on physiological Traits}

The summary of the analyses of variance indicated that the genotype of the chickens significantly $(\mathrm{P}<0.05)$ affected rectal temperature, pulse rate and respiratory rate (physiological) from week 1 to 24 weeks (Table 1). Rectal temperature, pulse rate and respiratory rate are the most important determinants in the adaptation of poultry to the tropical environment. They also to a large extent determine the profitability of the poultry enterprise.

\subsection{Effect of Genotype on haematological and serum biochemical Traits}

The result of the haematological indices are presented in Table 2 .There were significant difference $(\mathrm{P}<0.05)$ among genotypes in the mean values for red blood cells counts, hemoglobin concentration, Packed Cell Volume, Mean Corpuscular Volume, Mean Corpuscular Hemoglobin and Mean Corpuscular Hemoglobin Concentration. The serum biochemical parameters of the three chickens genotype is presented in Table 3 . The mean values of total protein, albumin, urea, cholesterol, creatinine, full blood count, calcium and phosphorus of the genetic group were significantly $(\mathrm{P}<0.05)$ different

\section{Discussion}

The least square means and the significant test of the effect of genetic group on the physiological traits reveled significant difference between all the parameters measured among the genetic group. On rectal temperature, observation ranged from $40.09 \pm 0.21^{\circ} \mathrm{C}$ to $41.68 \pm 0.03^{\circ} \mathrm{C}$. Animals with naked neck genotype had the highest mean value, while the normal feather genotype had the least value. Rectal temperature was very high in week 20 for naked neck genotype as a result of genetic differences. However, the rectal temperature was quite stable throughout the experiment from week 1 to week 24. This correspond with the findings of Teeter et al [11] that normal body temperature of the chickens is $41^{\circ} \mathrm{C}$ and Justin [1] reported that body temperature of the birds must remain within the narrow limits of $41^{\circ} \mathrm{C}\left(106^{\circ} \mathrm{F}\right)$ if its welfare is to be safeguarded and production maintained at acceptable levels. The observed significant $(\mathrm{P}<0.05)$ difference in rectal temperature corresponds with the reports that notable difference between breeds is in their ability to regulate rectal temperature [12] at normal environmental conditions as reported by West [13].

The observed result with respiratory rate was significantly affected by genotype. It follows the same pattern observed with rectal temperature. The naked neck had the highest range $(64.80 \pm 2.60 \mathrm{breaths} / \mathrm{min})$ while 
frizzled feathered genotype had the least value of $22.00 \pm 1.49$ beats $/ \mathrm{min}$. This corresponds with the reports of Robert [14] that the size of the animal also affects the respiratory rate. The heavier breed, which were the Naked neck, had the highest respiratory rate for most part of the experiment followed by the normal, which could be attributed to the fact that the rate of metabolism is higher in heavier birds since they posses larger surface area and which could leads to increase in rate of exchange of gases. Heat production according to DEFRA [15] affected by body weight, species, breed, level of production, level of feed quality and to a lesser extent, by the amount of activities and exercise. This implies that, as ambient temperature increases, birds start to pant to lose heat which is accompanied with increase in respiratory rates. However, for each genotype across the 24 weeks, an increase in respiratory rate as age progresses was observed.

The pulse rate observed ranged from $234.00 \pm 17.21$ to $397.001 \pm 19.15$ beats $/ \mathrm{min}$. the highest pause rate was also recorded for naked neck genotype and in week 4 . There exist a fluctuation in pause rate week by week; the fluctuations in pause rate might have been as a result of external factors such as temperature, diseases conditions or intense activities by the animals $[16,17]$. It means they were well-adapted to the prevailing harsh production environment because of natural selection which may have aided them in the accumulation of genes for adaptability.

Heat stress index is defined as a function of the deviation of actual from targeted environmental temperature and bird's age and the higher the index, the higher the severity of the heat stress [4]. The Dominant Blue chickens had the highest mean value while the local had the least. This implies that the exotic chickens used in this study were more stressed than their counterparts. The highest heat stress decreased with age, an indication of adaptation to tropical environment as they advance in age.

There were significant difference $(\mathrm{P}<0.05)$ between genotypes in the mean values of count $\mathrm{WBC}, \mathrm{RBC}$ $\mathrm{HB}, \mathrm{PCV}, \mathrm{MCV}, \mathrm{MCH}$ ) and $\mathrm{MCHC}$. The mean values obtained in the present study falls within the normal physiological range $[18,19,20]$. The higher PCV, HB and WBC values in the frizzle genotype are in agreement with the findings of Clubb and Schubot [21]. Although these higher values were attributed to a higher weight gain as well as a reduction in heat load the frizzle genotype, reported PCV was higher in naked neck genotype compared to that of the fully feathered genotype [22]. This could be a boost in the growth and productive life of the former. However, the present results are inconsistence with the PCV, RBC and HB values reported by Oke et al. [23], where no significant $(\mathrm{p}<0.05)$ genotype effect was observed. These variations could be attributed to environment and season since PCV in birds is reported to be seriously affected by stress or adverse conditions [24]. Similar observations were reported by Njidda et al. [25] who observed decreased PCV (24-27\%) as a result of adverse weather conditions. The result of the RBC also showed that the feed contained high quality dietary protein and the animals were free from diseases since the values fall within the normal range. $\mathrm{Hb}$ values of the experimental birds were higher than the values reported by Njidda et al. [25]. The different environment might be the possible explanation, though the result shows that the vital physiological relationship of $\mathrm{Hb}$ with oxygen in the transport of gases (Oxygen and Carbondioxide) to and from the tissues of the body has been maintained and was normal. The significant increase in the WBCs must have agreed with the reports of Emenalom et al. [26] who reported that it is probable that the birds were immunologically challenged. The elevated leukocyte counts of all the birds could be a physiological adjustment presented against negative antigenic effect. This may largely be informed of the associated inherent resistance to tropical diseases. It is noteworthy that the subsisting ecological conditions support several vectors and parasites of economic significance.

The mean values of total protein, albumin, urea, cholesterol, creatinine, full blood count, calcium and phosphorus of the genetic group were also significantly $(\mathrm{P}<0.05)$ influenced. However, the present results reported for total protein, albumin, urea, cholesterol, creatinine are inconsistent with the values of by Ladokun $e t$ al., [27] who observed no significant $(\mathrm{P}<0.05)$ genetic effect in their study. Moreover, the normal feather genotype had a significantly higher $(\mathrm{P}<0.05)$ albumin content $1.90,1.74,1.62,1.61$ and $1.49 \mathrm{ml}$ and a lower $165.22 \%$ full blood count values. The present findings are inconsistent $i$ with the report of earlier workers [21, 28]. Serum parameters are important in the proper maintenance of the osmotic pressure between the circulating fluid and the fluid in the tissue space so that the exchange of materials between the blood and cells could be facilitated. They also contributed to the viscosity and maintenance of the normal blood pressure and PH. The lower creatinine which is a waste product found in the muscle from a high energy storage compound. All the values obtained from the minerals were all within range as reported by other authors [29,30]. The implication is that breeds/strain may affect the electrolyte values. The significant genotypes and sex differences found for haematological and serum biochemical values are suggestive of the existence of genetic variation. The higher values of calcium, phosphorus, urea and albumin in females than males might be attributed to various physiological factors associated with females. For examples, during egg formation and egg-laying, females are in restless and excited condition [30]. 


\section{Conclusion}

The study showed that genetic variation in the genetic makeup of the chickens accounted for observed differences in rectal temperature, pulse rate, respiratory rate and heat stress index. This is an indication that rectal temperature, pulse rate, respiratory rate,values can be used in the classification of birds into genetically distinct subgroups. The use of Naked neck chicken that confer some extent of tolerance to harsh tropical environment should be encouraged especially in crossbreeding programmes in order to produce individuals that are adaptive and more productive.

\section{References}

[1] Justin,E (ADAS)( 2004), "Heat stress in poultry-solving the problems".In The 14th Annual Conference of theAnimal Science Association of Nigeria. Ladoke Akintola University of Technology, Ogbomoso, Oyo State,Nigeria.14th-17th September, 2009. Pp 89-92.

[2] Reece,F.N and B.D,Lott,(1983), "The effect of temperature and age on body weight and feed efficiency of broiler chickens". Poult Sci. 62; 1906-1908

[3] Smith, A.J. (2001), “ Poultry”. The tropical Agriculturalist. Revised Edition. Macmillian Education Ltd. London. Pp 243.

[5] Jain, N. C.,( 1986), "Schalm's Veterinary Haematology' (4th ed). Lead and febiger, philadelpho, USA.

[6] Slot, C. (1965)," Plasma creatimine determination". A new and specific reaction method scand. J. lab. Invest, 17; 381.

[7] Henry, R.J., Sobel C. Kim J. (1957), "A modified carbonate phosphotungstale. Method for determination of uricacidand comparison with spectrometric uric acid method". Anim J.Clin. Pathol., 28: 152 - 160.

[8] Roschlan P., Bernt e., Gruber W., (1974), “Enzymatische best immung des gesatcholesterive in serum“ J. clin Chem. Brochem. 12: $403-407$.

[9] SAS/STAT. (1999), "SAS User's guide"; statistic released version 8.0. Statistical analysis system institute Inc. Cary. NC

[10] Gomez, A.K and Gomez, A.A (1984), "Statistical procedures for Agricultural Research 2nd Edition,John Wiley and Sons New York U.S.A 680pp.

[11] Teeter,R.G.,Smith,M.Oand Wiernusz,C.J (1992).Broiler acclamation to heat distress and feed intake effects onbody temperature in birds exposed to thermonuetral and high and high ambient temperatures.Poultry.Sci.71:1101-1104.

[12] Finch, V.A., (1986), "Body temperature in beef cattle, its control and relevance to production in Tropics". J. Anim. Sci: 62-531.

[13] West, J. W., (1999)," Nutritional strategies for managing the heat stress in dairy cow". J. Anim. Sci.,77 2:21-35.

[14] Robert, A. V. (1994), "Raising healthy goats under primitive conditions", Overview of general information, Christian Veterinary Mission, Washington, USA. Pp $12-18$.

[15] Defra,(2003), "Heat stress in poultry Solving the problem". www.defra.gov.uk/animal/welfare/pdfhstress05.

[16] Bahga, C.S., Dingra, D.P., Gangwar, P.C. and Methta, S.N. (1984), "Diurnal variations in the physiological responsesof buffalos under the evaporative cooled and heat stressed conditions". Ind J. Anim. Res. 181: 17-21.

[17] Umaru, M. (1988), "Disease detection": What a livestock farmer should know. Niger. Livestock Farmer $81: 31$ - 34

[18] Ikhimioya,I; Arijeniwa,A; Oteku,I.T and Ahmend, A (2000), "Prelimanary investigation on the haematology of Nigerian indigenous chickens". Proc.5th Anu Conf. Animal. Sci. Assoc. Nigeria. Sept.19-22 Port Harcourt, Nigeria,pp:10-12.

[19] Islam,M.S; Lucky,N.S;Islam,M.R;Ahadi,A;DasB.R; Rahman,M.M and Siddini,M.S.I (2004), "Haematological parametersof Fayoumi,Asil and local chickens reared in Sylhet region in Bangladesh". Int J.Poult Sci.,3:144- 147.

[20] Simaraks,S.O; Chinrasi, O and Aengwanich,S (2004), "Haemotological electrolyte and serum biochemical values of the thai indigenous Chickens (Gallus domesticus) in north eastern Thailand". Song Klanakarim. J.Sci.Tech., 26: 425-430.

[21] Clubb,S.L and Schubot,R.M (1991), "Haematological and serum biochemical reference intervals in juvenile Cock". J.Vet,Med.,5:16-26

[22] EL-Safty,S.A; Ali,U.M; and Fathi,M.M (2006), "Immunological parameters and Laying performance of Naked neck and normally feathered genotypes of chickens of Egypt'. Int, J Poult,Sci., 5:780-785.

[23] Oke,U.K; Herbert,U; Ebuzoeme,C.O and Nwachukwu,E.N (2007), "Effect of genotype on the Haematology of Nigerian local chickens in a humid tropical environment'. In :Proc 32nd Annual Conference of NSAP. Calabar, Nigeria 18th -21st March, pp 123-125.

[24] Campbell, T. W. 1995 Avian Haematology and Cytology, 2nd Ed. Iowa State University Press, Ames, Pp 3-5.

[25] Njidda, A. A., J.U. Igwebuike, A.A. Ngoshe, and A.O. Tijjani, 2006. Effect of substituting maize with graded levels of cane molasses on the performance of broiler finisher birds in the semi- arid region of Nig. J. Sub Agric. and Environ. 8 1: 1-13

[26] Emenalom, O. O., B.O. Esonu, E.B. Etuk, and C. Anaba, 2009. Effect of Mucuna pruriens (Velvet Bean) leaf mealon performance and blood composition of finisher broiler chickens. Nig J Anim Prod. 36 1: 52 - 60.

[27] Ladokun,A.O; Yakubu,A; Otite,J.R; Omeje,J.N; Sokunbi,O.A and Onyeji,E (2008), "Haematological and serum Biochemical indices of Naked Neck and Normally Feathered Nigerian Indigenous Chickens in a Sub Humid Tropical Environment'. Int J of Poult Sci 7 1: 55-58.

[28] Mitruka,B.M and Rawnsley,(1977), "Clinical Biochemical and Haematological Refference Values in Normal experimental Animals". Masson Publishing U.S.A.,pp:88-90.

[29] Anon, (1980), "Guide to the Care and Use of Experimental Anima"l. Vol, 1Canadian Council of Animal Care, Ottawa,Onotario Canada. pp 85-90

[30] Iheukwumere.F.C. and Herbert,U (2003), "Physiological responses of broiler chickens to quantitative water restriction, haematology and serum biochemistry". Int, J.Poult.Sci. 2:117-119. 
Table 2 A: Effect of Genotypes on heat tolerance traits.

\begin{tabular}{|c|c|c|c|c|c|}
\hline $\begin{array}{l}\text { Ages in } \\
\text { Weeks }\end{array}$ & Genotype & $\begin{array}{l}\text { Rectal } \\
\text { Temperature } \\
\left({ }^{\circ} \mathrm{C}\right)\end{array}$ & $\begin{array}{l}\text { Respiratory } \\
\text { Rate } \\
\text { (Beat/Min) }\end{array}$ & $\begin{array}{l}\text { Pulse rate } \\
\text { (Breath } / \mathrm{min})\end{array}$ & $\begin{array}{l}\text { Heat stress } \\
\text { index }\end{array}$ \\
\hline \multirow[t]{5}{*}{1} & normal & $40.66 \pm 0.07^{2 b}$ & $43.40 \pm 1.02^{2 b}$ & $317.00 \pm 6.69^{2 b}$ & $1.18=0.03^{b}$ \\
\hline & naked neck & $40.46=0.14^{6}$ & $47.80=0.74^{2}$ & $344.50=6.90^{\mathrm{z}}$ & $1.20=0.03^{6}$ \\
\hline & Frizzled & $40.93=0.10^{2}$ & $46.20=2.45^{26}$ & $311.00=11.83^{6}$ & $1.36=0.15^{6}$ \\
\hline & Dominant Blue & $40.19=0.07 \mathrm{c}$ & $42.20=1.63^{6}$ & $282.50=14.28^{c}$ & $1.37=0.11^{2}$ \\
\hline & Dominant Black & $39.19=0.14^{e}$ & $43.40=1.60^{2 b}$ & $217.50=7.81^{d}$ & $1.73=0.07^{\mathrm{z}}$ \\
\hline \multirow[t]{5}{*}{4} & normal & $40.27=0.17^{b}$ & $40.40=1.08 \mathrm{e}$ & $277.00=15.68 \mathrm{c}$ & $1.33=0.08^{\mathrm{cb}}$ \\
\hline & naked neck & $41.11=0.07^{2}$ & $70.20=2.40^{2}$ & $343.50=27.78^{\mathrm{c}}$ & $1.45=0.07^{6}$ \\
\hline & Frizzled & $41.17 \pm 0.07^{2}$ & $48.40=1.51^{6}$ & $336.00 \pm 9.55^{6}$ & $1.26=0.06^{6}$ \\
\hline & Dominant Blue & $40.61=0.07^{6}$ & $52.40=1.33^{6}$ & $235.50=7.93 \mathrm{c}^{-}$ & $1.95=0.0 \mathrm{~s}^{2}$ \\
\hline & Dominant Black & $39.63=0.17 e^{a}$ & $43.00=1.42^{c}$ & $265.50=22.86^{\mathrm{c}}$ & $1.54=0.10^{6}$ \\
\hline \multirow[t]{5}{*}{8} & normal & $40.77=0.07^{2 b}$ & $42.60=1.84 c^{c}$ & $288.50=14.31^{b}$ & $1.32=0.08^{6}$ \\
\hline & naked neck & $40.83=0.14^{2}$ & $52.40 \pm 1.58^{2}$ & $334.00 \pm 5.82^{2}$ & $1.35=0.04^{6}$ \\
\hline & Frizzled & $40.59=0.49^{26}$ & $51.80=1.52^{26}$ & $312.50=7.29 \mathrm{ab}$ & $1.45=0.08^{6}$ \\
\hline & dominant Blue & $40.52=0.10^{6}$ & $47.20 \pm 1.61^{6 c}$ & $214.50 \pm 8.52^{\mathrm{a}^{-}}$ & $1.94=0.10^{\mathrm{a}}$ \\
\hline & dominant Black & $40.83=0.07^{2}$ & $50.60 \pm 1.7^{26}$ & $258.00=13.13^{e^{-}}$ & $1.75=0.10^{2}$ \\
\hline \multirow[t]{5}{*}{12} & normal & $41.33=0.07^{\mathrm{a}}$ & $52.00=2.64^{6}$ & $351.50=27.58^{26}$ & $1.35=0.10^{6}$ \\
\hline & naked neck & $41.26=0.08^{2 b}$ & $50.20=1.41^{b}$ & $392.50=10.3 \mathrm{~s}^{\mathrm{2}}$ & $1.11=0.03^{6}$ \\
\hline & Frizzled & $41.36=0.04^{2}$ & $50.40=1.34^{b}$ & $329.00=12.35^{b}$ & $1.36=0.07^{6}$ \\
\hline & Dominant Blue & $41.30=0.00^{26}$ & $62.20=3.17^{2}$ & $196.50=17.91 \mathrm{c}$ & $3.21=0.34^{2}$ \\
\hline & Dominant Black & $41.13=0.05^{6}$ & $5.80 \pm 2.08^{6-1}$ & $332.00 \pm 20.54^{6}$ & $1.45=0.10^{\mathrm{b}}$ \\
\hline
\end{tabular}

a.b. Means in the same column with different superscripts are significantly different $(\mathrm{P}<0.05)$

Table 2 B: Effect of Genotypes on heat tolerance traits.

\begin{tabular}{|c|c|c|c|c|c|}
\hline $\begin{array}{l}\text { Ages in } \\
\text { Weeks }\end{array}$ & Genotype & $\begin{array}{l}\text { Rectal } \\
\text { Temperature }\left({ }^{\circ} \mathrm{C}\right)\end{array}$ & $\begin{array}{l}\text { Respiratory Rate } \\
\text { (Beat/Min) }\end{array}$ & $\begin{array}{l}\text { Pulse rate } \\
\text { (Breath } / \mathrm{min})\end{array}$ & $\begin{array}{l}\text { Heat stress } \\
\text { index }\end{array}$ \\
\hline \multirow[t]{5}{*}{16} & normal & $41.10=0.06^{b c}$ & $44.00=0.92^{c}$ & $349.00=0.92^{\circ}$ & $1.09 \pm 0.04^{b}$ \\
\hline & naked neck & $41.34=0.09^{26}$ & $47.40=1.60^{66}$ & $396.50 \pm 21.77^{\mathrm{zb}}$ & $1.05 \pm 0.04^{6}$ \\
\hline & Frizzled & $41.06=0.8^{6}$ & $49.60=1.60^{6}$ & $310.00=12.80^{\mathrm{e}}$ & $1.42=0.0 \mathrm{~s}^{2}$ \\
\hline & Dominant Blue & $41.19=0.12^{2}$ & $55.60=1.76$ & $446=28.56^{2}$ & $1.11=0.05^{b}$ \\
\hline & Dominant Black & $41.43=0.11^{\mathrm{z}}$ & $51.60=2.74^{2 b}$ & $432=12.70^{2}$ & $1.03=0.05^{b}$ \\
\hline \multirow[t]{5}{*}{20} & normal & $41.78=0.13^{2}$ & $45.00=1.29^{b}$ & $330.00=17.93^{6-}$ & $1.21=0.05^{26}$ \\
\hline & naked neck & $41.77 \pm 0.08^{2}$ & $55.58 \pm 1.96^{2}$ & $424.21=37.99^{2}$ & $1.21=0.07^{26}$ \\
\hline & Frizzled & $41.05=0.08^{c}$ & $46.00=2.00^{6}$ & $344.00=8.12^{6}$ & $1.58=0.06^{26}$ \\
\hline & Dominant Blue & $41.49=0.08^{b}$ & $47.20=2.20^{6}$ & $391.00=15.01^{26}$ & $1.07 \pm 0.07^{\mathrm{b}}$ \\
\hline & Dominant Black & $41.09=0.04^{c}$ & $48.00=2.93^{6}$ & $346.50=36.92^{b}$ & $1.30=0.09^{2}$ \\
\hline \multirow[t]{5}{*}{24} & normal & $41.16=0.05^{2}$ & $49.00=1.61^{2}$ & $366.00=12.66^{2}$ & $1.17=0.05^{56}$ \\
\hline & naked neck & $40.45=0.13^{6}$ & $46.60=0.73^{\mathrm{a}}$ & $359.50=7.56^{2}$ & $1.12=0.03^{26}$ \\
\hline & Frizzled & $40.98=0.10^{2}$ & $33.20=3.32^{b}$ & $284.50=16.69^{2}$ & $1.01=0.08^{6}$ \\
\hline & Dominant Blue & $41.06=0.04^{2}$ & $44.60=0.90^{\mathrm{a}}$ & $302.50=6.84^{6 c}$ & $1.26=0.04^{2}$ \\
\hline & Dominant Black & $41.11 \pm 0.0 \mathrm{~s}^{2}$ & $45.00 \pm 2.77^{2}$ & $319.50 \pm 1.14^{6}$ & $1.21 \pm 0.07^{2}$ \\
\hline
\end{tabular}

a.b. Means in the same column with different superscripts are significantly different $(\mathrm{P}<0.05)$

Table 3: Effect of Genotupes on haematologcal traits.

\begin{tabular}{|c|c|c|c|c|c|}
\hline Traits & Normal & Frizzled & Naked neck & Dominant Blue & Dominant Black \\
\hline WBC $\left(\times 10^{3} / \mu\right)$ & $21.50 \pm 2.21^{\mathrm{d}}$ & $28.13=0.06^{2}$ & $27.65 \pm 0.16^{b}$ & $27.23=0.53^{6}$ & $28.23=0.20^{2}$ \\
\hline $\mathrm{RBC}\left(\times 10^{6} / \mu\right)$ & $2.85=0.15^{d}$ & $3.32=0.01^{b}$ & $3.18=0.09 \mathrm{c}$ & $3.18=0.24^{\mathrm{c}}$ & $3.55=0.02^{2}$ \\
\hline PCV $(\%)$ & $37.73=1.91^{\mathrm{d}}$ & $46.40=0.40^{2}$ & $42.60=1.06^{6}$ & $40.80=2.88^{\circ}$ & $46.60=0.34^{2}$ \\
\hline $\mathrm{Hb}(\mathrm{g} / \mathrm{d} 1)$ & $12.78=0.92^{\circ}$ & $15.96=0.09^{2}$ & $14.29=0.43^{b}$ & $12.36=1.33^{6}$ & $16.37=0.08^{2}$ \\
\hline MCV (fl) & $133.86=1.54^{d}$ & $141.19=2.10^{2}$ & $134.91=2.67^{6}$ & $130.82=3.48^{\circ}$ & $134.45=1.03^{6}$ \\
\hline $\mathrm{MCH}(\mathrm{pg})$ & $44.53=0.96^{d}$ & $48.57=0.09^{2}$ & $45.32=0.53^{\mathrm{c}}$ & $41.57=0.90^{\mathrm{a}}$ & $45.63=0.05^{6}$ \\
\hline $\mathrm{MCHC}(\%)$ & $33.21=0.62^{\mathrm{c}}$ & $34.37=0.90^{2}$ & $33.52=0.21^{6}$ & $31.79=0.94^{\mathrm{d}}$ & $34.28=0.07^{2}$ \\
\hline
\end{tabular}

$a, b, c, d,:$ Means in the same row with different superscripts are significantly different $(p<0.05)$

Table 4: Effect of Genotypes on Serum biochemical traits.

\begin{tabular}{|c|c|c|c|c|c|}
\hline Traits & Normal & Frizzle & Naked neck & Dominant blue & Dominant black \\
\hline Total protein(ml) & $5.20 \pm 0.18^{6}$ & $6.16 \pm 0.19^{2}$ & $4.62 \pm 0.03^{\mathrm{d}}$ & $4.63 \pm 0.03^{d}$ & $4.94 \pm 0.25^{c}$ \\
\hline Albumin(m1) & $1.90=0.07^{\mathrm{z}}$ & $1.74=0.05^{b}$ & $1.61=0.03^{\mathrm{c}}$ & $1.62=0.02^{6}$ & $1.49=0.11^{d}$ \\
\hline Cholesterol(mg/di) & $89.78=2.41^{\mathrm{c}}$ & $69.70=0.37^{0}$ & $93.00=4.51^{6}$ & $107.80=4.9 \mathrm{~s}^{2}$ & $71.60=11.54^{d^{-}}$ \\
\hline $\begin{array}{l}\text { Urea(m1) } \\
\text { (mill }\end{array}$ & $5.19=1$ & $4.60=0.37^{6}$ & $3.90=0.23^{\mathrm{dd}}$ & $3.40=0.22^{\mathrm{d}}$ & $0.30 \mathrm{~b}^{\mathrm{c}}$ \\
\hline Creatinine (m1) & $0.44=0.04^{b-}$ & $0.86=0.08^{2}$ & $0.45=0.11^{b}$ & $0.46=0.31^{b}$ & $0.46=0.18^{6}$ \\
\hline $\mathrm{Rb} s \mathrm{Q}$ & $165.22=0.63^{\circ}$ & $212.00 \pm 3.58^{2}$ & 179.8 & $\pm 3.18^{d}$ & $184.00=0.42^{b}$ \\
\hline Calciur & $9.34=$ & $9.35=0.19 \mathrm{c}$ & 11.30 & $10.51=0.03^{6}$ & $8.47=0.25^{\mathrm{d}}$ \\
\hline Phosphorus(mg/di) & $4.14=0.04^{6--}$ & $4.34=0.07^{6}$ & $3.37 \pm 0.11^{\mathrm{c}}$ & $5.50=0.31^{2}$ & $4.17=0.18^{b}$ \\
\hline
\end{tabular}

a. $b, c, d$ : Means in the same row with different superscript are significantly different $(\mathrm{p}<0.05)$ 